\title{
ALFONSO GROSSO Y LA LITERATURA DE VIAJES DE LOS AÑOS SESENTA: DOS MIRADAS A LAS TIERRAS ANDALUZAS
}

\author{
Lucía Montejo Gurruchaga \\ UNED
}

\begin{abstract}
In the light of censorship dossiers and other documents unpublished up to now, I analyse in this essay two travel books which Alfonso Grosso wrote between 1961 and 1962, in collaboration with two friend writers. The first one, Por el río abajo, was composed with Armando López Salinas, the second one, A poniente desde el Estrecho, with Manuel Barrios. This sub-genre played a major role in counteracting the celebratory discourse of travel books written by authors ideologically close to the Franco regime. However travel literature of this period did not always succeed in avoiding government control. Por el río abajo could never be published in Spain, permission was denied and was printed during the Spanish political transition. A poniente desde el Estrecho remained in oblivion until 1990 for other reasons.
\end{abstract}

Alfonso Grosso inicia su trayectoria creadora dentro de la tendencia realista en los albores de la década de los sesenta. En menos de seis años va a publicar cuatro novelas, $L a$ zanja (1961), Un cielo dificilmente azul (1961), Testa de copo (1963) y El capirote (1966). La crítica coincidirá, de forma unánime, en su adscripción al realismo social, y destacará la cuidada técnica, la estructura elaborada, el rápido ritmo narrativo y la calidad de sus obras ${ }^{1}$. Algunos estudiosos calificaron al autor sevillano como un realista nuevo ${ }^{2}$, alabaron su preocupación formal y lingüística superior a los usos más frecuentes en los escritores de su generación ${ }^{3}$ y calificaron la primera etapa de Grosso de asombrosa coherencia ${ }^{4}$. Con todos estos testimonios, no cabe duda de que Grosso expresa las circunstancias sociales de la época y adopta un compromiso social e ideológico con un lenguaje renovado hecho, en muchas ocasiones, de imágenes sensoriales ${ }^{5}$.

Aunque todos los especialistas coinciden en que la etapa realista de Grosso (1961-1966) la componen obras dignas de aprecio, ya que aprovecha categorías esenciales de la

\footnotetext{
${ }^{1}$ P. Gil Casado, La novela social española (1920-1971)), Barcelona, Seix Barral, 1973 (2 ${ }^{\mathrm{a}}$ ed.), p. 96.

${ }^{2}$ Juan Ignacio Ferreras, Tendencias de la novela española actual 1931-1969, París, Ediciones Hispanoamericanas, 1970, p. 187.

${ }^{3}$ Santos Sanz Villanueva, Historia de la novela social española (1942-1975), Madrid, Alhambra, 1980, p. 655.

${ }^{4}$ Ignacio Soldevila Durante, La novela desde 1936, Madrid, Alhambra, 1980, p. 275.

${ }^{5}$ José Antonio Fortes, que ha estudiado la biografía y la trayectoria literaria del autor sevillano, profundiza en estos aspectos en la extensa introducción que preparó para la edición de La zanja (Madrid, Cátedra, 1984, pp. 11138) y en el volumen Palabras contra el olvido. El novelista Alfonso Grosso (Instituto de Estudios Almerienses. Diputación de Almería, 2003), en el que recopila algunos de los trabajos que, sobre el escritor, publicó en las décadas ochenta y noventa.
} 
corriente, innova y crea un peculiar realismo, los estudios sobre el autor siguen siendo escasos. La crítica atendió puntualmente la publicación de las cuatro novelas del periodo, tanto en España como en el extranjero, aunque, por lo general, con breves reseñas y de escasa profundidad ${ }^{6}$. Aunque han aparecido algunas monografías en los últimos años y se han reeditado algunas de estas obras, aún está lejos de recibir la atención que debería haber suscitado ${ }^{7}$. Pero Grosso no fue sólo autor de novelas; sus relatos, libros de viajes y reportajes de carácter vario, escritos algunos en esta misma década, han recibido una atención aún menor. Los libros de viajes, escritos con algunos escritores de su generación, han permanecido durante muchos años en el olvido por motivos extraliterarios.

En este artículo me propongo analizar, a la luz de los expedientes de censura, que permanecían inéditos hasta ahora, sus dos libros de viajes escritos en los años sesenta, Por el río abajo y A poniente desde el Estrecho (entre dos banderas); ambos son de autoría compartida.

Aunque la crítica alude a los problemas reiterados de Grosso con la censura franquista desde el principio de su creación, desde la publicación de La zanja en 1961, no han visto aún la luz los expedientes de censura de sus obras ${ }^{8}$. Los informes y manuscritos de estas

${ }^{6}$ F. Santos Fontenla, La zanja, Ínsula (noviembre 1961). R. Vázquez Zamora, "Alfonso Grosso, La zanja", Destino (21 de octubre, 1961). D. Santos, "Dos novelas de Alfonso Grosso: La zanja y Un cielo dificilmente azul", Madrid, Pueblo, Suplemento Literario (28 de abril, 1962). P. Ferneux, La fossé, Bruxelles, Le Peuple (5 de febrero, 1963). G. Pillement, "La fossé, par A. Grosso", Nouvelles Littéraires (4 de abril, 1963). J. Batlló, "Alfonso Grosso: Testa de copo", Cuadernos Hispanoamericanos, 171 (marzo, 1964), 647-650. Iliá Ehrenburg, "Alfonso Grosso y El capirote », Moscú, Literaturas Extranjeras (1966). Suñén. L., "Alfonso Grosso y El capirote", La Estafeta Literaria, 547 (septiembre 1974).

${ }^{7}$ Teresa Ballo Moreno, Alfonso Grosso y su novela, Tesis Doctoral, Granada, Universidad de Granada, 1976. José Antonio Fortes, De Alfonso Grosso. (La muerte en la novela), Publicaciones Ayuntamiento de Vélez-Málaga, 1981. Maritza Hartman Merin, Alfonso Grosso y el realismo social, Michigan, University Microfilms International, 1985. Lynn Kiefer Talbot, The Novelistic Techniques of Alfonso Grosso, Michigan, University Microfilms International, 1985. José Antonio Fortes, Palabras contra el olvido: el novelista Alfonso Grosso, Almería, Instituto de Estudios Almerienses, Diputación de Almería, 2003. Son monografías que analizan las tres etapas de la narrativa de Grosso, la realista, la experimental -que se inicia en 1968 con Inés just coming- y la última, que arranca en 1976 con La buena muerte, en la que asume los postulados de la novela de la transición política. Casi todas sus novelas del periodo realista se han reeditado con cierta regularidad y por editoriales diversas: La zanja, Barcelona, Destino, en 1961 y en 1982; Espasa-Calpe, 1978, con prólogo de Eduardo Mendicutti; Madrid, Cátedra, 1984, edición de José Antonio Fortes y Barcelona, Orbis, 1984. Un cielo dificilmente azul, Barcelona, Seix Barral, 1961 y 1972, y Círculo de Amigos de la Historia, 1978. Testa de copo, Barcelona, Seix Barral, 1963 y 1971. El capirote, México, Joaquín Mortiz, 1966; Barcelona, Seix Barral, 1974; Madrid, Espasa-Calpe, 1984, con prólogo de José Manuel Caballero Bonald y recientemente en Barcelona, Libanó, 2002.

${ }^{8}$ José Antonio Fortes, en la Introducción que preparó para la edición de La zanja en 1984, observa que se trata de la única edición completa, ya que incorpora (entre corchetes) los fragmentos que tuvieron que suprimirse en la primera edición (Barcelona, Destino, 1961) a causa de la censura. Aunque reseña el número de expediente 935/61- añade que deja para más adelante el estudio de los documentos que contiene. Ignoro si lo ha llevado a cabo. He consultado todos los expedientes de la obra de Grosso, archivados en el A.G.A. (Archivo General de la Administración), en Alcalá de Henares y he comprobado que contienen abundante y variada documentación; los informes de los distintos censores, cartas de los editores, del propio autor y otros documentos, ponen de manifiesto el calvario de mutilaciones y denegaciones que sufrió la obra del escritor durante más de veinte años. En los pocos años que nos ocupan, los que comprenden su etapa realista, presentará a censura ocho obras de carácter vario. Sólo una-Testa de copo (1963)- salió indemne. Se le denegó el permiso de publicación de tres, El capirote (1962), Por el río abajo (1962) y De romería (1963). Las otras cuatro sufrieron tachaduras y mutilaciones en mayor o menor grado. 
dos obras, no solo desvelarán el carácter y alcance de los textos denegados o mutilados, sino que aclararán además algunas confusiones o errores sostenidos hasta hoy sin demasiados elementos de juicio.

Los estudios ya clásicos sobre la práctica censoria en las cuatro décadas en las que sus normas estuvieron vigentes hablan de la severidad con que sus principios se aplicaron en la inmediata posguerra, poniendo el énfasis en el anticomunismo del sistema y en la defensa de los valores de la civilización cristiana. En los años cincuenta, con el desarrollo que vive España y los cambios profundos en la sociedad, se inicia una moderada política de apertura universitaria e intelectual. Muchos escritores realistas se toparon con la censura en los años en que Gabriel Arias Salgado (1956-1962) fue Ministro de Información y Turismo. Abellán califica esta etapa como momento de rigidez total en materia de censura, de un sabor integrista fuera de lo común'. Sufrieron el acoso del órgano censor, entre otros, los hermanos Goytisolo, Jesús López Pacheco, Armando López Salinas, Antonio Ferres, Dolores Medio, Ana María Matute, y algunas de las obras de estos autores, como las de Grosso, fueron, en el mejor de los casos, mutiladas y en otros casos, suspendida o denegada su publicación ${ }^{10}$. En la década de los sesenta no podremos hablar de menor intensidad en el ejercicio de la censura. En 1966 se creará la Ley de Prensa e Imprenta, impulsada por el entonces Ministro de Información y Turismo, Manuel Fraga Iribarne (1962-1969) -la llamada ley Fraga-, que suprimía la obligación de censura previa, con la consiguiente apariencia de tolerancia, pero limitaba en gran medida el margen de maniobra de autores y editores ${ }^{11}$.

Autores y críticos reconocen que la existencia de la censura provocó la aparición de un lenguaje literario específico. La escritura realista rehabilita, por cuestiones estratégicas, la opacidad del significado. Juan Goytisolo decía al respecto: "Si algún mérito hay que reconocer a la censura es el de haber estimulado la búsqueda de las técnicas necesarias al escritor para burlarla e introducir de contrabando en su obra la ideología o temática prohibidas. Bregados con la experiencia de nuestros fracasos, los escritores hemos

\footnotetext{
${ }^{9}$ Manuel Abellán, Censura y creación literaria en España (1939-1976), Barcelona, Península, 1980, p. 151.

${ }^{10}$ Hay testimonios que avalan este acoso en José María Martínez Cachero, La novela española entre 1939 y 1980. Historia de una aventura, Madrid, Castalia, 1985, pp. 243, 299, 395, en Censura y literaturas peninsulares. Diálogos Hispánicos de Amsterdam, 5 (1987), edición de Manuel L. Abellán, y en Geneviève Champeau, "Censure, morale et écriture à l'époque du realismo social, Dossier Censure, critique politique et création sous le Franquisme, Mélanges de la Casa de Velázquez, XXVII, 3, Époque contemporaine, 1991, pp. 139-161. Pueden verse también mis artículos sobre la relación entre el discurso de autora y la censura en este mismo periodo: «Dolores Medio en la novela española del medio siglo. El discurso de su narrativa social”, Epos, XVI (2000), pp. 211-225; "Las mujeres escritoras de los años cincuenta: al margen de las tendencias dominantes", Las mujeres escritoras en la historia de la Literatura Española, Lucía Montejo Gurruchaga, Nieves Baranda (Coordinadoras), Madrid, Estudios de la UNED, 2002, pp. 153-166; "La narrativa realista de Concha Alós", Anuario de Estudios Filológicos, XXVII (2004), pp. 175-190.

${ }^{11}$ Para una detallada información sobre la organización de este mecanismo de control, la eficacia y la influencia que alcanzó, remito a Manuel L. Abellán, Censura y creación literaria en España (1939-1976), op.cit.; R. Gubert, La censura. Función política y ordenamiento jurídico bajo el franquismo (1939-1975), Barcelona, Península, 1981; Hans-Jörg Neuschäfer, Adiós a la España eterna. La dialéctica de la censura. Novela, teatro y cine bajo el franquismo, Barcelona, Anthropos, 1994; J. Sinova, La censura de la prensa durante el franquismo, Madrid, Espasa Calpe, 1989. Ruiz Jiménez, ministro de Educación, había intentado durante los años de su mandato -1951 a 1956- una tímida liberalización en el ámbito cultural, pronto abortada por las fuerzas ultraconservadoras, encabezadas por el clero, que desencadenaron una reacción que tuvo como consecuencia un retroceso irreversible.
} 
aprendido el manejo de la astucia. Numerosas novelas y poemas que salen a la luz en España rehuyen la ley o la eluden ingeniosamente"12. Baltasar Porcel remachaba en la misma idea con estas palabras: "La censura me ha hecho crear, supongo que como a todo el mundo, un lenguaje determinado, un lenguaje de alusiones, un lenguaje en espiral, que el lector que también está acostumbrado a leer en este lenguaje ya ha entendido lo que tú le decías, porque la censura no es solamente un hecho represivo, sino que este hecho represivo crea a la vez un lenguaje y éste puede ser hasta cierto punto diáfano como si dijeras las cosas directamente"13. La novela comprometida (dice Ignacio Soldevila) se escribe con tan gran cuidado de explotar al máximo las ambigüedades de situación y de lenguaje que, velis nolis, alcanza una calidad estética indiscutible ${ }^{14}$.

Pero al mismo tiempo, los escritores de la generación realista van a sondear en la literatura de viajes, en este subgénero literario recurrente en las distintas épocas y que utilizarán para contrarrestar el discurso de los libros de viajes escritos por autores franquistas.

El primero de los libros de viajes, Por el río abajo, que Grosso escribe entre 1960 y 1961 con el escritor Antonio Ferres, tiene una larga historia de denegaciones. El manuscrito del segundo, A poniente desde el Estrecho, firmado con Manuel Barrios en 1962, estuvo perdido durante años y no fue publicado hasta 1990.

La larga tradición inmediata de la literatura de viajes, procedente de los autores de la generación del 98 (Unamuno, Azorín, Baroja), la retoman los escritores que surgen tras la guerra civil y se convierte en una expresión literaria fecunda en la generación del medio siglo. Muchos de los libros de viajes que se escribirán durante las décadas cincuenta, sesenta y setenta, atienden a todas las regiones de España y contrastan con los reportajes de viajes que distintos periódicos y revistas de inspiración franquista publicaban en los que, de forma apologética, se ensalzaba el pintoresquismo y el encanto de las distintas comarcas. Son una respuesta necesaria a los tópicos de las campañas turísticas y van a dar lugar a obras de características definidas ${ }^{15}$. Se escriben libros de viaje bajo la presión de la urgencia histórica con el objetivo de paliar las lagunas provocadas por la carencia de una Prensa de Información veraz ${ }^{16}$. Antonio Ferres incidía en esta idea con estas palabras: "Creo que la

\footnotetext{
12 Juan Goytisolo, "Los escritores españoles frente al toro de la censura", El furgón de cola, Barcelona, Seix Barral, 2001, p. 56 (1 $1^{\text {a }}$ ed. 1967).

${ }^{13}$ Antonio Beneyto, Censura y politica en los escritores españoles, Madrid, Euros, 1975, p. 23.

${ }^{14}$ Ignacio Soldevila Durante, La novela desde 1936, Madrid, Alambra, 1980, p. 217.

${ }^{15}$ Geneviève Champeau, en Les enjeux du réalisme dans le roman sous le franquismo, Madrid, Casa de Velázquez, 1993, pp. 39-68, analiza un buen número de reportajes publicados en El Español (órgano oficioso de la acción política del Gobierno), entre 1953 y 1959. Constata que, aunque están dedicados a distintos pueblos y regiones de España, hay una clara predilección por Castilla La Vieja, cuna de la Nación española, y por Andalucía en sus dos caras, la de las ricas regiones agrícolas y la del turismo a las áridas estepas almerienses.

${ }^{16}$ Como muestra de la proliferación de libros de viajes de signo variado en la década de los sesenta destaco los siguientes títulos: Juan Goytisolo, Campos de Níjar (1960) y La chanca (1962). Antonio Ferres y Armando López Salinas, Caminando por las Hurdes (1960). Juan Antonio Pérez Mateos, Las Hurdes, clamor de piedras. José Antonio Vizcaíno, Caminos de La Mancha (1962). Francisco Candel, Viaje al Rincón de Ademuz (1962). Ramón Carnicer, Donde las Hurdes se llaman Cabrera (1964), Antonio Ferres, Tierra de olivos (1964), José Antonio Vizcaíno, De Roncesvalles a Compostela (1965) y Caminos de La Mancha (1965), Javier Alfaya y Armando López Salinas, Viaje al país gallego (1967), Jesús Torbado, Tierra mal bautizada (1969), Jorge Ferrer-Vidal, Viaje por la Sierra de Ayllón (1970).
} 
aparición de la llamada novela social se debe a una necesidad de los escritores de acercarse a la realidad concreta (histórica, social, etc.) que nos era ocultada sistemáticamente a los españoles. Esto, que es evidente en la novela, es absolutamente obvio en los libros de viajes, claro. A mí, al menos, esta necesidad de salir a ver, de palpar las cosas con mis propios sentidos, es lo que me impulsó a escribir los libros de viajes. Había que conocer y señalar esta realidad, ya que la prensa (por ejemplo) era triunfalista y lo silenciaba todo ${ }^{17}$."

Cela inicia el género en el periodo de posguerra aunque sus libros de viajes ofrecen una visión literaria, no testimonial. La crítica ha manifestado poco interés por este subgénero, al que ha dedicado poco tiempo y espacio. Algunos estudiosos han señalado algunas características comunes a la literatura de viajes de los escritores de los sesenta, como son: la precisa datación del recorrido, el modo indirecto en la narración y el uso de la tercera persona en busca de la verosimilitud y de la apariencia de imparcialidad. Se han fijado asimismo, en la descripción pormenorizada de personajes, paisajes, costumbres, y han puesto de relieve el diálogo abundante, el lenguaje instantáneo y coloquial, el vocabulario local y el uso de la fonética popular. A estos rasgos distintivos hay que añadir la intención testimonial y el compromiso social, la denuncia de las carencias e injusticias que padecen las gentes, que se manifiesta con una decidida postura ideológica de izquierdas ${ }^{18}$.

En la nota introductoria escrita para anunciar la primera edición de Por el río abajo, fechada en París en enero de 1966, los autores (Alfonso Grosso y Armando López Salinas) ponen en conocimiento del lector que "en el mes de agosto de 1960 realizaron un viaje a pie por tierras de la Baja Andalucía, exactamente a lo largo del delta del Guadalquivir". Añaden que "razones obvias de explicar, directamente relacionadas con la censura previa, impidieron entonces que las impresiones escritas durante su viaje pudieran ser publicadas en España". La nota concluye con estas palabras: "Desgraciadamente todas las observaciones sociológicas continúan teniendo vigencia a pesar de los años transcurridos" ${ }^{\prime 19}$.

Por el río abajo iba a ser publicado por Seix Barral en su colección Biblioteca Breve y la editorial solicita al Ministerio de Información y Turismo, Sección de Orientación Bibliográfica, el permiso de edición, como era preceptivo, el 15 de Febrero de $1962^{20}$. Junto a la solicitud entrega el manuscrito, que está archivado en el A.G.A. con otros documentos,

\footnotetext{
${ }^{17}$ Antonio Núñez, "Encuentro con Antonio Ferres", Ínsula, 220 (marzo 1965), p. 6.

${ }^{18}$ Gil Casado dedica el capítulo 7 de La novela social española (1920-1971), op. cit. pp. 415-454 a analizar las características de los libros de viajes. Santos Sanz Villanueva en Historia de la novela social española (19421975), op.cit., dedica el capítulo 5, pp. 777-801, a comentar distintos libros de la literatura viajera en la España de posguerra aunque, en páginas precedentes, ha analizado otros muchos en el estudio que dedica al conjunto de la obra narrativa de sus respectivos autores.

${ }^{19}$ Alfonso Grosso y Armando López Salinas, Por el río abajo, Paris, Editions de la Librairie du Globe, colección Ebro, 1966. La segunda edición de este libro, con prólogo de Antonio Ferres, se llevó a cabo en España después de la transición política (Bilbao, Ediciones Albia, 1977). En el prólogo Ferres dice que se trata de "un testimonio vivo, trepidante, tembloroso, comprometido hasta el latir de la sangre, escrito bajo los cánones del realismo documentalista (...) en una atmósfera de miedo, de falsos ídolos, bajo una dictadura terrorista, cuando un hombre cualquiera había de huir, temer y disimular su rabia".

${ }^{20}$ Se le asignó el número de expediente 827-62.
} 
y unos días después, el 26 de Febrero, un lector redacta un informe en el que, entre otras, hace las siguientes observaciones ${ }^{21}$ :

"La obra describe, sobre un fondo de resentimiento social una Andalucía de pesadilla, donde "enjambres de moscas se comen los cuerpos desnudos de los niños" (8), donde para cobrar subsidio es necesario tener padrino (21), donde los latifundistas (cita abundantes nombres) y sus capataces se regalan a costa del sudor y hambre de los braceros. No falta alusión al Ejército (43), al trato de las Colonias Penitenciarias (130), al Régimen, etc. De léxico repetidamente soez. NO AUTORIZABLE".

El informe del censor pone el acento en aquellas páginas (que señala entre paréntesis) en que se denuncian la miseria, las condiciones de vida de pobreza y atraso de estas tierras de Andalucía, se critica las arcaicas estructuras agrarias, a los que las sustentan en su propio beneficio, y se acusa de esta situación a los pilares del régimen franquista.

Por el río abajo discurre en el delta del Guadalquivir, tierra fecunda. Su tesis es clara: si la gente que describe y puebla sus páginas es pobre, se debe a que la tierra está en manos de unos pocos. La situación creada por el latifundio origina los conflictos entre jornaleros y terratenientes. Esta es la situación que el libro describe. Pero no se limita al testimonio o a la denuncia de las estructuras sociales dominantes y opresoras. Es también un testimonio de las costumbres locales, una aproximación lingüística a las gentes de esta región andaluza, a sus manifestaciones literarias. Predominan las descripciones de la tierra, de los cultivos, y los narradores, parcamente, sin largas diatribas, y en tono sereno que sólo excepcionalmente deja paso al desahogo personal, denuncian injusticias o las ponen en boca de los segadores, pescadores, jornaleros.

La Sección de Inspección correspondiente comunica la resolución a la editorial y, en nombre de esta, Carlos Barral interpone Recurso de Reposición ${ }^{22}$. Escribe a la Dirección General, y, entre otras cosas, alega:

"CONSIDERANDO que los hechos de tipo sociológico, que (...) ponen de manifiesto los autores (...), han sido puestos de relieve por las autoridades españolas y muy en especial por Su Excelencia el Jefe del Estado (...) y que en ningún caso la situación de escasa evolución económica de la zona (...) puede imputarse a abandono por parte del actual Régimen español (...), y que es precisamente nuestro actual Gobierno el primero que se propone seriamente poner remedio al atraso económico de la baja Andalucía.

CONSIDERANDO que en el libro (...) no se contiene afirmaciones contrarias a la ortodoxia cristiana o a la doctrina política del Movimiento, ni se describen hechos o escenas que pudieran ser calificadas de tendenciosas o inmorales.

SUPLICA que le sea concedida la autorización ${ }^{23}$."

\footnotetext{
${ }^{21}$ Los censores -lectores en el argot ministerial- se identificaban por un número y, por lo general, estampaban al final del informe una firma ilegible, sobre todo si eran negativos. Algunos eran funcionarios del régimen franquista o personal eventual de escasa formación, pero había otros relacionados con el mundo literario escritores o críticos en determinadas revistas y periódicos- o con el mundo universitario. Dada la relevante función de la Iglesia católica, los lectores eclesiásticos tenían, en muchas ocasiones, la última palabra, como tendremos ocasión de comprobar. Copio los informes tal y como aparecen en los documentos originales.

${ }^{22}$ Era frecuente, he encontrado muchos casos en mis años de investigación en el Archivo, solicitar una nueva revisión del libro, aunque la reapertura del proceso no significara un cambio de sentencia.

${ }^{23}$ Esta carta está archivada junto al expediente. La defensa del libro por parte del editor e incluso del propio autor o autores, aunque no era práctica generalizada, sí era frecuente sobre todo cuando se trataba de una editorial de
} 
Un mes más tarde, la Sección de Orientación Bibliográfica se aviene a reabrir el proceso y lo hace de la mano de un nuevo lector, de P. Álvarez Turienzo ${ }^{24}$, que emite, el 30 de marzo, el siguiente informe:

"[...] El relato tiene intención social, fijándose expresa y casi exclusivamente en las condiciones lamentables del obrero agrícola, en situación habitual de paro, en contraste con el señorito, dueño de las tierras. Los autores fueron buscando eso solamente y eso es lo que encontraron. Queremos decir que la pintura es muy parcial. Por eso, la protesta, legítima de fondo, acaba siendo tendenciosa. Lo es [...] por cierta desconsideración latente hacia la autoridad, en la forma de la guardia civil, por cierta solapada crítica del régimen [...]."

El censor acota como censurables párrafos o frases que aparecen en las páginas siguientes del manuscrito: $6,24,51,80,106,120,130,137,138,140$, y añade que, si se suprimen, el libro PUEDE AUTORIZARSE.

Cuando se produce una clara disparidad de criterios, la superioridad opta en todos los casos por demandar un nuevo informe, siempre a alguien de jerarquía superior, que cinco días más tarde, y con firma ilegible, redacta un nuevo comunicado en el que, entre otras cosas, se señala:

"Lo que bien pudiera haber sido un objetivo y realista libro de viajes [...], no es más que un relato abiertamente parcial y marcadamente tendencioso. Sorprende que los autores de este libro (...) no hayan visto más que lo que se recrean en destacar: explotación humana, miseria acumulada, paro obrero casi constante, hambre exagerada, brutal incultura, abandono público (...). De ahí la parcialidad, la recóndita intención de los autores Grosso y López Salinas, que abren su relato con unas estrofas de Miguel Hernández. Estrofas, en falsía, por otra parte, ya que España no es solamente de gañanes, pobres y braceros, como el verso afirma. Estimamos, en consecuencia, que esta obra no debe autorizarse."

Añade que, si a pesar de lo expuesto se decidiera su publicación, deberían suprimirse las frases o párrafos marcados en las páginas siguientes: $6,8,10,16,17,21,22,24,51,56,57$, $69,70,73,80,83,98,99,101,106,114,120,130,137,138,140,141,153$.

El manuscrito de Por el río abajo iba precedido por unos versos de Miguel Hernández que respaldan las preocupaciones vertidas en sus páginas por los autores ${ }^{25}$. Los tres censores coinciden en algunas de las múltiples tachaduras y mutilaciones, y todos reiteran

peso o de un autor o autores relevantes. Había dinero y prestigio en juego y había que defenderlos. Barral fundamenta su alegato aludiendo al viaje que Franco hizo en 1961 por Andalucía en el que descubre casi por casualidad que todavía había chabolas. Véase al respecto el volumen de J. Antonio Bisecas y Manuel Tuñón de Lara, España bajo la dictadura franquista (1939-1975), Barcelona, Labor, 1980, p. 333.

${ }^{24}$ Lector eclesiástico que, aunque su veredicto afecta a un considerable número de páginas, en contra de lo que cabía esperar, se muestra algo más benévolo.

${ }^{25}$ Son los siguientes: "Jornaleros: España, loma a loma/ es de gañanes, pobres y braceros./ ¡No permitáis que el rico se la coma,/ jornaleros!". Con estos versos termina el poema titulado "Jornaleros" de Viento del pueblo, poesía de combate, de solidaridad con el pueblo que sufre y de denuncia de las injusticias. Hay a lo largo de todo el libro una notable tendencia estética que se refleja en la presencia de la poesía de tipo tradicional cantada por el pueblo, en las alusiones a poetas como Juan Ramón Jiménez, Lorca. De este último los autores intercalan estos cuatro octosílabos de la "Canción del gitano apaleado" del Poema del cante jondo: "Veinticuatro bofetadas./ Veinticinco bofetadas;/ después, mi madre, a la noche,/ me pondrá en papel de plata". Recuerdan estos versos en un momento en que se cruzan con "dos números de la Guardia Civil". Por lo general, en estas citas ocultan el apellido del autor y la fuente. Son estrategias que utilizan para burlar la censura y, en esta ocasión, estos versos no fueron señalados por el censor. 
la imparcialidad del relato. Lo tildan de tendencioso y de destilar resentimiento social porque dirige sus críticas hacia la oligarquía terrateniente, hacia la estructura agraria arcaica causante del paro y la emigración, porque pone de manifiesto el atraso y la pobreza de las gentes de la región y acusa de estas causas al Régimen y a sus Instituciones.

A continuación pondré algunos ejemplos de tachaduras propuestas para que el lector pueda darse cuenta de la actuación censoria y el alcance de sus decisiones. Los censores señalan -y mutilan- algunas de las líneas en las que, por boca de unos jornaleros, los narradores denuncian las prebendas otorgadas por el Estado a grandes personalidades del Ejército por su decisiva participación en la Cruzada liberadora, en la Guerra Civil. Son estas:

- Gonzalo, el hijo del general Queipo, tiene muchas fincas por esa parte. Gonzalo es Teniente Coroné de Aviación.

-La ciudad de Sevilla le regaló un cortijo por los servicios prestados cuando la guerra.

-Se lo regaló al padre, al general -aclara Manuel al tiempo que se sirve un nuevo vaso de vino",26

Las políticas agrarias de la Segunda República siguen siendo la lejana esperanza de los jornaleros de Andalucía, como testimonian en sus diálogos, y las críticas se dirigen siempre a la oligarquía terrateniente, parásitos que viven lejos y desconocen la situación del campo. Abierta y amargamente se quejan de esta situación que se repite desde hace más de un siglo, y comentan: - ¡Aquí sí que es buena tierra. Pero, como si fuera mala. La tierra buena no es para el que la trabaja ${ }^{27}$. Estas denuncias no pasan desapercibidas y los censores pondrán sobre ellas el lápiz rojo.

Tampoco podían dejar pasar los censores la denuncia al trato cruel y vejatorio que se daba a los prisioneros políticos vencidos tras la Guerra Civil, y estas líneas fueron, también, íntegramente mutiladas:

"Los veintidós kilómetros del que va de los Palacios al Aeropuerto de San Pedro lo hicieron a pico y pala los presos políticos. Dos mil hombres con turnos de día y turnos de noche en la Colonia Penitenciaria Militarizada -contesta Alfonso-. Recuerdo haberlos visto trabajar cubiertos sólo con un taparrabos y custodiados por la Guardia Civil. Son cosas que no se olvidan. Era cuando iba a veranear a Málaga, tendría poco más de diez años. Al pasar el tren por los Merinales, mis hermanos y yo nos asomábamos a la ventanilla del tren para mirarles. Una vez, un hombre que iba en el departamento dijo: Miren cómo trabajan los rojillos. Así aprenderán otra vez a no insultar a los señores ${ }^{28}$."

\footnotetext{
${ }^{26}$ Así aparece este párrafo, y los que a continuación señalaré, en el manuscrito. Alfonso Grosso y Armando López Salinas, Por el río abajo, Paris, Editions du Globe, 1966, p. 34. Citaré por esta primera edición de aquí en adelante. El lector debe poner atención en el uso de determinadas figuras retóricas a lo largo del relato que tienen por objeto eludir la censura. Son, por lo general, tropos de carácter semántico que implican relaciones de contigüidad, como formas eufemísticas, metonimias o sinécdoques. En esta ocasión, se utiliza un singular para referirse a una realidad plural pero que sólo representa a una parte; el topónimo -Sevilla- no implica a la ciudadanía, sino a las fuerzas vivas de la ciudad.

${ }^{27}$ Ibidem, p. 128.

${ }^{28}$ Ibidem, p. 166. El último campo de concentración de republicanos hechos prisioneros durante la Guerra Civil estuvo en Los Merinales (Sevilla) y se cerró en 1962. En este tiempo, los presos reconstruyeron las infraestructuras en régimen de trabajos forzados.
} 
El 10 de Abril declaran concluso el expediente manteniendo la anterior DENEGACIÓN. Por el río abajo, por tanto, solo podrá ser publicado en España después de la transición política, quince años después de haber sido escrito.

Son escasas las noticias sobre el libro de viajes A poniente desde el Estrecho. Los críticos que en algún momento lo mencionan, señalan la autoría compartida y añaden que corrió la misma suerte que Hacia Morella, que Grosso escribió con José Agustín Goytisolo, que tampoco vio la luz ${ }^{29}$. Grosso escribió A poniente desde el Estrecho con el escritor, también sevillano, Manuel Barrios en el verano de 1962. Sin embargo, la primera edición se ha producido en fechas muy recientes, se llevó a cabo en 1990 En él Alfonso Grosso figura como único autor, y el título presenta un desarrollo explicativo ${ }^{30}$. El equipo editorial, que firma la introducción del libro, silencia el asunto de la autoría, intenta aclarar el subtítulo y justificar el retraso en la publicación por los avatares censorios que sufrió. Lo hace con estas palabras:

"Grosso, inserto con apasionado entusiasmo en el grupo de los que esgrimen la literatura como arma de combate, también toma un día carretera y manta, trazándose una ruta que habría de ir de bandera a bandera; es decir, de la bandera inglesa de Gibraltar hasta la bandera norteamericana de Rota. Demasiado fuerte para la censura, por lo que cambia este título por el de A poniente desde el Estrecho. Lo malo fue que la censura no se conformó con proscribir tan sólo el título; la obra fue rechazada de plano y en el olvido permaneció durante todos estos años, sin que nadie, ni siquiera el autor, volviera a ocuparse de ella".

La historia es, en realidad, bastante distinta, como he podido constatar en el A.G.A. La editorial Seix Barral solicita a la Dirección General de Información, Sección de Orientación Bibliográfica, el 8 de marzo de 1963, el permiso de publicación de la obra de Alfonso Grosso y Manuel Barrios A poniente desde el Estrecho para su colección Biblioteca Breve $^{31}$. Unos días más tarde (el 22 de marzo), un lector emite un escueto informe en el que hace las siguientes observaciones:

"1. Pretende ser un periplo desde Algeciras a Cádiz, pero [...] es una descripción entre periodística y literaria de tipos y paisajes [...], con cierto aire de España negra, pues hay tendencia a resaltar la miseria y la suciedad. Ignoro la parte gráfica de la obra.

2. Hay soltura y facilidad literaria, pero se abusa un poco del realismo en el lenguaje empleado por los personajes $[\ldots]$

A continuación comunica que puede publicarse.

La Dirección General de Información, atenta a las observaciones del censor, solicita a Seix Barral, mediante nota, que presente las fotografías que acompañarán al texto, que son

\footnotetext{
${ }^{29}$ Tanto José Antonio Fortes (Palabras contra el olvido. El novelista Alfonso Grosso, op.cit. p. 30) como Felipe B. Pedraza y Milagros Rodríguez Cáceres (Manual de literatura española. XIII. Posguerra: narradores, Navarra, Cénlit, 2000, p. 863) lo han dado por perdido en fechas aún recientes.

${ }^{30}$ Alfonso Grosso, A poniente desde el Estrecho (entre dos banderas), Sevilla, Rodríguez Castillejo, editor, 1990.

${ }^{31}$ Se le asigna el expediente núm. 1495-63. Junto a la solicitud aparece en el Archivo el manuscrito, firmado por ambos autores y otros documentos, a los que me referiré a continuación, y que se hacen públicos por primera vez. El título del manuscrito es $A$ poniente desde el Estrecho. Si los autores han practicado la autocensura, táctica común en aquellos momentos, no hay indicios para confirmarla.
} 
inmediatamente enviadas y aprobadas ${ }^{32}$. Pero cumplido este trámite, y sin motivo aparente, se emite un segundo informe, que apoya la resolución del primero y describe el libro como "un relatito documental de un paseo en barco de pesca desde Algeciras a Cádiz en el que se nos cuenta usos y costumbres y describen tipos marineros [...]". A lo que añade el censor añade que PROCEDE SU AUTORIZACIÓN ${ }^{33}$ ".

Ese mismo día se remite a Seix Barral la tarjeta de autorización, pero la publicación no se llevó a cabo.

A poniente desde el Estrecho presenta las mismas características que Por el río abajo ${ }^{34}$. Este subgénero, elemento clave en la narrativa de la época, es esencial en el dispositivo realista porque borra los signos de la literatura, de la ficción. Da cuenta de un viaje real y, en esta ocasión, el preciso espacio descrito es el recorrido del viajero desde la bandera inglesa de Gibraltar hasta la norteamericana de la base militar de Rota. La estructura del relato está determinada por la progresión del viaje, que se hace más verosímil con la inclusión de mapas del itinerario y fotos. Los personajes remiten a personas supuestamente reales -a los que se les asignan nombres o apodos- encontradas en el recorrido, los pescadores, los taberneros, los vendedores de moluscos y crustáceos, lo que refuerza la ilusión referencial. El discurso se acerca al esquema de representación del modelo periodístico, pero bajo la aparente difusión de hechos documentales se percibe el testimonio de denuncia de la realidad socioeconómica y política del país, que se aligera y suaviza, también en esta ocasión, con alusiones y referencias literarias ${ }^{35}$. El testimonio y las denuncias de las injusticias y carencias que la región padece, el regalado vivir de los señoritos y la explotación a la que someten a los pobres, el hambre y la miseria de muchos pueblos, la falta de trabajo, se destapan y exponen sin disimulos.

Mediante las descripciones vivas y pormenorizadas, el narrador describe así la vida en un barrio de Barbate:

"Cinco mil metros cuadrados donde se hacinan más de tres mil familias en tabucos de trozos de madera carcomida, latas de conservas, sacos y piedras. Las callejuelas se cruzan sin orden, y los niños juegan desnudos en los arroyos de aguas residuales bajo el sol, entre moscas y

\footnotetext{
${ }^{32}$ Es característica generalizada en los libros de viajes que los textos se acompañen con fotografías que aportan un valor documental. Con ellas se pretende representar las descripciones y fijar las imágenes que se plasman en el texto. Son, además, la prueba visual de lo descrito o narrado. Los autores pretenden, con la inclusión de las imágenes, atajar las reiteradas denuncias de imparcialidad y manipulación de la realidad.

${ }^{33}$ Este nuevo e innecesario informe, es una prueba de la meticulosidad con que se examina la obra de Grosso, que podría explicarse por los motivos siguientes. Los archivos de la Sección se mantenían escrupulosamente al día y, en estas mismas fechas, en febrero de 1963, se acaba de fallar el veredicto de otra obra del autor sevillano, De Romería; denegarán su publicación y no podrá publicarse, con un cambio de título, hasta 1981 (Con flores a María, Madrid, Cátedra). Pero, además, no era la primera denegación que el autor sufría.

${ }^{34}$ Mucho se ha escrito sobre la arbitrariedad con la que actuaban los censores. Este es un buen ejemplo.

${ }^{35}$ Hay inclusiones de canciones del cante jondo, alusiones a Alberti y a Marinero en tierra, a Vargas Vila (polemista escritor colombiano, enfrentado al gobierno conservador, al clero, al imperialismo yanqui y los dictadores hispanoamericanos, lo que le procuró menosprecio y censura), a Cervantes en sus avanzadas como comisario por ciudades, villas y aldeas, recorriendo caminos y hospedándose en inhóspitas ventas, que magistralmente retratara en el Quijote; de todas estas citas y alusiones se sirven los autores para recalcar su denuncia de miserias e injusticias en las tierras andaluzas.
} 
perros hambrientos. Viejas mujeres cubiertas de harapos se despiojan unas a otras, sentadas o en cuclillas a la puerta de las chozas ${ }^{36}$."

Estas y otras muchas de las descripciones que se suceden a lo largo del libro ponen sobre el tapete y con la misma crudeza, las mismas difíciles circunstancias sociales que se describen en Por el río abajo y endémicas en Andalucía, como se observa en el texto siguiente:

"El viajero no se extraña de esta hospitalidad que pudiera resultar excesiva a los que no han comprendido aún a los hombres humildes de Andalucía, que tantas veces, huyendo de su tierra, se han extendido por toda la geografía peninsular y media Europa, empujados por los motivos de siempre: "Líbreme Dios de la enfermedad que baja de Castilla y de la hambre que sube de Andalucía" ${ }^{\prime 37}$.

En ocasiones, el narrador parece reclamar o defender alguno de los largos litigios del régimen político. En un momento del trayecto habla con un cabo de la Policía Armada que está en la Aduana española de Gibraltar. Siguiendo la técnica que empleara en Por el río abajo, cede la palabra al personaje, que se erige en portavoz de la denuncia con estas palabras:

- ¿Puedo sacar fotos?

- Las que quiera. Aquí no hay secretos militares ni nada que esconder. Pasada la alambrada, ya es otra cosa.

- A pesar de ella, el contrabando será inevitable.

- Es asunto de carabineros, no nuestro. Del contrabando y de los obreros que trabajan dentro, en el arsenal y en los astilleros, vive el Campo de Gibraltar. Si un día no dejaran entrar un solo hombre, los ingleses tendrían que coger el petate y tomar carretera y manta. Pero no es posible. Serían quince mil hombres más con los brazos cruzados. Ya se ha notado la visita de la Reina Isabel. A partir de entonces empezaron los impedimentos, y La Línea y Algeciras ya no son lo que fueron siempre.

- Algún día la bandera inglesa desaparecerá del Peñón y se clavará otra en él $1^{38}$

El manuscrito presenta algunas diferencias respecto al texto que se publicó en 1990.

1. En el manuscrito, que Grosso firmaba con Manuel Barrios, como ya se ha dicho, los narradores, tal y como hicieran en Por el río abajo, aparecen designados como los viajeros o los amigos, y con frecuencia se produce la identificación

\footnotetext{
${ }^{36}$ Alfonso Grosso, A poniente desde el Estrecho (entre dos banderas), op, cit., p. 71.

${ }^{37}$ Ibidem, p. 22. Conviene recordar que de 1959 a 1961 se abrió la espita de la emigración de los trabajadores a Europa: 169.000 en los primeros tres años, sin contar la no controlada por el Instituto de Emigración. Sus efectos beneficiosos para el Régimen franquista fueron inmediatos: evitaba el peligro del paro forzoso, era fuente de divisas y disminuía la tensión en las zonas conflictivas del país. Véase: J. Antonio Biescas y Manuel Tuñón de Lara, op. cit., p. 299.

${ }^{38}$ Ibidem, p. 27. En 1954, con motivo del viaje de la reina Isabel II de Inglaterra por las naciones de la Commonwealth y colonias inglesas, se incluye la visita a Gibraltar como etapa final. El gobierno español solicita que se suspenda para evitar enconos, pero se desoye la petición. El gobierno español da entonces por terminada la política de tolerancia y aplica de modo estricto las disposiciones legales vigentes en materia de aduanas, tránsito de personas (suprimió el consulado), vehículos, mercancías. Reivindicó, de nuevo, Gibraltar ante la ONU el 15 de enero de 1957. Puede verse al respecto: J. Antonio Bisecas y Manuel Tuñón de Lara, op. cit., p. 164.
} 
autores-narradores lo que propicia que en ocasiones aparezcan con sus propios nombres: Alfonso y Manolo. En la primera edición el narrador queda reducido al viajero y desaparece todo indicio de autoría compartida.

2. La dedicatoria se mantiene: "Para el Capitán Argüello, patrón de pesca de Calafell", pero en la edición de 1990, mediante asterisco se añade: "Dadas sus aficiones marineras, así era conocido Carlos Barral en el círculo de sus amigos".

3. En el manuscrito, bajo el título, leemos: “(A bordo del JOVEN BEATRIZ, EL CEPORRO, MAURICIO ROJAS Y ADRIANO, julio 1962). Y en la página siguiente se da cuenta de las fotos que el libro va a incluir: Fotos de los autores. Fotos submarinas de Jesús Navarro, del Centro de Recuperación e Investigaciones Submarinas (CRIS). Gráfico del sonar del "JOVEN BEATRIZ". Cartas Marítimas: Instituto Hidrográfico de la Marina ${ }^{39}$. Estas referencias han sido suprimidas y las fotografías cambiadas por otras en la edición de 1990.

4. Han sido también suprimidos dos párrafos del inicio del libro. El relato se inicia así: "El JOVEN BEATRIZ utiliza artes de cerco y jareta. Hasta 1958 sus singladuras no llegaban más allá de Larache. Hoy se ve obligado a continuarlas ante la prohibición del Gobierno de Rabat de pescar en aguas jurisdiccionales marroquíes- hasta Cabo Bojador." Los dos párrafos, que copio a continuación, y que figuran en el manuscrito, han sido suprimidos en la edición de 1990:

"Su armador y patrón de pesca, Ambrosio Gil Sánchez, de treinta y nueve años, tiene los ojos azules, es achaparrado, nervioso y viste el traje de patén gris característico de los campesinos andaluces. Se toca con una boina negra y cecea con el tono dengoso del Campo de Gibraltar.

A bordo del JOVEN BEATRIZ y de otros pesqueros de calado semejante, los viajeros han visitado los puertos más importantes entre las dos bahías: Algeciras $\left(36^{\circ}\right.$ $\left.7^{\top} \mathrm{N} ; 5^{\circ} 25^{\top} \mathrm{W}\right)$ y Cádiz $\left(36^{\circ} 33,5^{\top} \mathrm{N} ; 6^{\circ} 18,5^{\top} \mathrm{W}\right)$, y creen que A PONIENTE DESDE EL ESTRECHO es el primer libro marítimo de viaje que se escribe con absoluta objetividad sobre una parcela determinada de la costa de España, aunque no olvidan que el tema de la mar ha sido ya profusamente tratado por otros escritores españoles, casi siempre, desgraciadamente, con más fantasía -ayudada por la socorrida terminología marinera- que sinceridad y realismo."

5. Hay algunas otras modificaciones, como la supresión de algunas frases de carácter explicativo con el fin de agilizar el relato, el cambio de algunas palabras consideradas de un lenguaje más académico o las supresiones de términos reiterativos o retóricos.

\footnotetext{
${ }^{39}$ Hay varios documentos que hacen referencia a estas fotografías y mapas. La Sección de Orientación Bibliográfica comunica a la editorial Seix y Barral, el 8 de abril de 1963, que la obra "podrá ser autorizada, previa presentación de las fotografías que llevará la misma." El 17 de mayo, la editorial contesta diciendo que "tiene el honor de ponerlas a su disposición, solicitando le sean devueltas, una vez examinadas, por carecer de otro juego de fotografías para imprimir en la publicación de la obra." El 8 de Junio solicita, mediante escrito, "le sean prestadas durante quince días, para poderlas incluir en la publicación de la misma (por no disponer de otro juego) y que serán devueltas une vez utilizadas". Al margen, alguien ha escrito: "Conforme". "Entregado".
} 
Sin embargo, y aunque $A$ poniente desde el Estrecho pasó la censura sin el menor contratiempo, como hemos comprobado, el libro no fue publicado y quedó olvidado durante décadas, pero en esta ocasión, los motivos no son imputables a la censura.

Analizados los dos libros de viajes, a la luz de los expedientes de censura y otros documentos, escritos en el breve espacio que comprende los años 1961 y 1962, constatamos que se trata de dos claras propuestas con las que sus creadores se proponen contrarrestar el discurso triunfalista de los libros de viajes escritos por autores cercanos al régimen franquista, lo que, en el caso de Por el río abajo, les acarreó graves problemas con el órgano censor, que denegó el permiso de publicación. Un caso distinto es $A$ poniente desde el Estrecho, que presenta las mismas características y que sin embargo eludirá la censura sin el menor contratiempo. Ninguno de los dos pudo ser publicado en su momento y han permanecido muchos años en el olvido.

\section{REFERENCIAS BIBLIOGRÁFICAS}

ABELlÁN, M., Censura y creación literaria en España (1939-1976), Barcelona, Península, 1980.

ABEllán, M., (ed.), Censura y literaturas peninsulares. Diálogos hispánicos de Amsterdam, 5 (1987).

BENEYTO, A., Censura y política en los escritores españoles, Madrid, Euros, 1975.

BIESCAS J. A. y TUÑÓN DE LARA, M., España bajo la dictadura franquista (19391975), Barcelona, Labor, 1980.

CHAMPEAU, G., "Censure, morale et écriture à 1'époque du realismo social”, Dossier Censure, critique politique et création sous le Franquisme, Mélanges de la Casa de Velázquez, XXVII, 3 (1991).

CHAMPEAU, G., Les enyeux du réalisme dans le roman sous le franquisme, Madrid, Casa de Velázquez, 1993.

FERRERAS, J. I., Tendencias de la novela española actual 1931-1969, París, Ediciones Hispanoamericanas, 1970.

FORTES, J. A., La zanja, Madrid, Cátedra, 1984.

FORTES, J. A., Palabras contra el olvido. El novelista Alfonso Grosso, Instituto de Estudios Almerienses. Diputación de Almería, 2003.

GIL CASADO, P., La novela social española (1920-1971), Barcelona, Seix Barral, 1973 ( $2^{\mathrm{a}}$ edición).

GOYTISOLO, J., "Los escritores españoles frente al toro de la censura", El furgón de cola, Barcelona, Seix Barral, 2001 (1 $1^{\text {a }}$ edición 1967).

GROSSO, A. y LÓPEZ SALINAS, A., Por el río abajo, Paris, Editions de la Librairie du Globe, 1966.

GROSSO, A., A poniente desde el Estrecho (entre dos banderas), Sevilla, Rodríguez Castillejo editor, 1990.

GUBERT, R., La censura. Función política y ordenamiento jurídico bajo el franquismo (/1939-1975), Barcelona, Península, 1985.

MARTÍNEZ CACHERO, J. M., La novela española entre 1939 y 1980. Historia de una aventura. Madrid, Castalia, 1985. 
NEUSCHÄFER, H. J., Adiós a la España eterna. La dialéctica de la censura. Novela, teatro y cine bajo el franquismo, Barcelona, Anthropos, 1994.

NÚÑEZ, A., "Encuentro con Antonio Ferres", Ínsula, 220 (marzo 1965), p. 6.

SANZ VILLANUEVA, S., Historia de la novela social española (1942-1975), Madrid, Alhambra, 1980.

SOLDEVILA DURANTE, I., La novela desde 1936, Madrid, Alhambra, 1980. 